Int. J. Dev. Biol. 56: 939-948 (2012)

doi: 10.1387/ijdb.120255ja

\title{
Above the borderland between normal and neoplastic development
}

\author{
JUAN ARÉCHAGA*,1 and IVAN DAMJANOV² \\ ${ }^{1}$ Laboratory of Stem Cells, Development and Cancer. Department of Cell Biology and Histology, Faculty of Medicine \\ and Dentistry, University of the Basque Country, Bilbao, Vizcaya, Spain and ${ }^{2}$ Department of Pathology and \\ Laboratory Medicine, The University of Kansas School of Medicine, Kansas City, Kansas, USA.
}

\begin{abstract}
This dialogue between the Editor-in-Chief of the Int. J. Dev. Biol. and a leading figure in human pathology and mammalian embryology highlights the close links between the biological interpretation of neoplasia and differentiation processes which normally occur during development, particularly in the case of teratomas. In addition, it emphasizes how a capacity for work, a firm will to progress, and enthusiasm for science and medical practice can overcome the not insignificant obstacles with which one meets during a life of scientific, academic and clinical dedication.
\end{abstract}

KEY WORDS: pathology, development, differentiation, teratoma, teratocarcinoma, germinal cell, cancer biology

It is not very frequent to find surgical pathologists or basic cancer biologists interested in embryology or in the essential problems of developmental biology such as induction, differentiation or cell migration. On the other hand, many contemporary scientists, who are competent in highly specialized techniques such as those of molecular biology, often lack that broad-based traditional knowledge of basic biology, zoology, pathology, experimental embryology, microscopy, history of science, etc. which confers upon the scientist that vision which enables a more profound understanding of the meaning and significance of the findings of their research. This lack of a broader scope in current educational programs is to be lamented. As quoted from the preface of a well known monograph on developmental aspects of neoplasia: Canyou imagine an individual studying fish scales if he had never even thought about a fish or has possibly never ever seen one? It is in this position that most authors of books about cancer have placed non-medical people. The authors have completely ignored the clinical phenomenology of cancer to discuss a highly specialized aspect of it. There are many scales, but no fish (Pierce et al., 1978).

The medical, scientific and humanistically solid personality of Professor Ivan Damjanov is the reverse side of that coin. He was born at the end of March of 1941, during the difficult times of the Second World War, in Subotica, a small town in the former Yugoslavia. During his childhood and adolescence, he suffered the penalties of life under a dark socialist regime in a country devastated, first by the German army and later by the communist partisans and the Soviets. However, between 1964 and 1966, he was able to obtain the degrees of MD and MSc at the University of Zagreb, today capital city of the independent Croatia. Then, he made his internship and residence in Pathology, first in the Dr. Mladen Stojanović Hospital and the Department of Pathology of the University of Zagreb and later, in the Cleveland Metropolitan General Hospital of Ohio and the Mount Sinai Hospital of New York, USA.

During 1969 Dr. Damjanov returned to Zagreb to do his PhD thesis under the guidance of Professor Nikola Škreb (1920-1992), a former pupil of Professor Albert Dalc in Belgium (Mulnard, 1992) and founder of the Croatian School of Mammalian Developmental Biology (Šerman, 1991; Švajger, 1991), starting simultaneously in that laboratory an important and long scientific collaboration with his friend and university comrade Davor Solter (Fig.1 A). Some time later, the young Ivan returned to the USA as postdoctoral fellow in the Fels Research Institute of Temple University in Philadelphia, returning again to Zagreb for a short time as Assistant Professor in the Department of Pathology of that Croatian University and definitively returning and remaining in the USA from 1973, first in Farmington, at the University of Connecticut and later in the Hahnemann Medical College and the Jefferson Medical College of Philadelphia for the period 1977-1994 (Fig. 1D and Fig. 2). Finally, he arrived to The University of Kansas Medical School, in Kansas City, as Professor and Chairman of the Department of Pathology, and remains there until today. A key feature during the most recent and longest American period in the scientific biography of Ivan Damjanov, was the connection and continuous stimulus and support of G. Barry Pierce (Fig. 1B), a great pioneer of the experimental pathology of teratocarcinoma and introductor

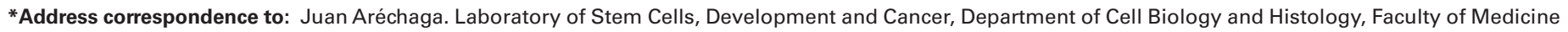
and Dentistry, University of the Basque Country, E-48940 Leioa,Vizcaya, Spain. Tel: +34-94-601-2883. Fax: +34-94-601-3266. E-mail: juan.arechaga@ehu.es
}

Final, author-corrected PDF published online: 13 December 2012.

ISSN: Online 1696-3547, Print 0214-6282

(c) 2012 UBC Press

Printed in Spain 
of the concept of differentiation of neoplasias, an anathema in the cancer biology research of his time. Pierce's stimulating concepts and experimental contributions opened the way to great discoveries in the present flourish of pluripotent stem cell research and transgenesis (Aréchaga, 1993).

Professor Damjanov is a very prolific scientific and medical writer. He is author of almost 400 publications including over 300 original peer-reviewed articles in the field of mammalian development, immunology and experimental and human pathology. He also wrote some 30 review articles and invited editorials, and contributed over 30 chapters to various books and monographs. He has written and or edited over 30 books, monographs and textbooks, some of which have been translated into foreign languages such as Chinese, Japanese, Russian, Greek, Spanish and Portuguese. Lately he has produced several audiovisual courses. He also had important editorial functions in well-recognized scientific journals and has received several international honors and prizes (Fig. 3).

In the following interview, I have tried to highlight the more interesting aspects of his academic personality and mayor scientific contributions, mainly in relationship with the field of teratomas and mammalian development, together with some questions about his personal opinions on the biology of ovarian teratomas.

In 1991 The International Journal of Developmental Biology published a Special Issue entitled "Developmental Biology in Yugoslavia". This was edited, under extremely difficult conditions, by the late Prof. Anton Švajger during the dramatic events of the civil war. The present situation in independent Croatia must be very different. To understand better the style of life in your homeland, please summarize for us what life was like in the former Yugoslavia during your childhood and adolescence.

I am not sure that I could answer your question and describe realistically and objectively the life in former Yugoslavia. From my current vantage point of a 71-year-old university professor, everything about my childhood appears rosy, even though I spent my first years in a poor and underdeveloped country ravaged by the Second World War and mishandled thereafter by communists.
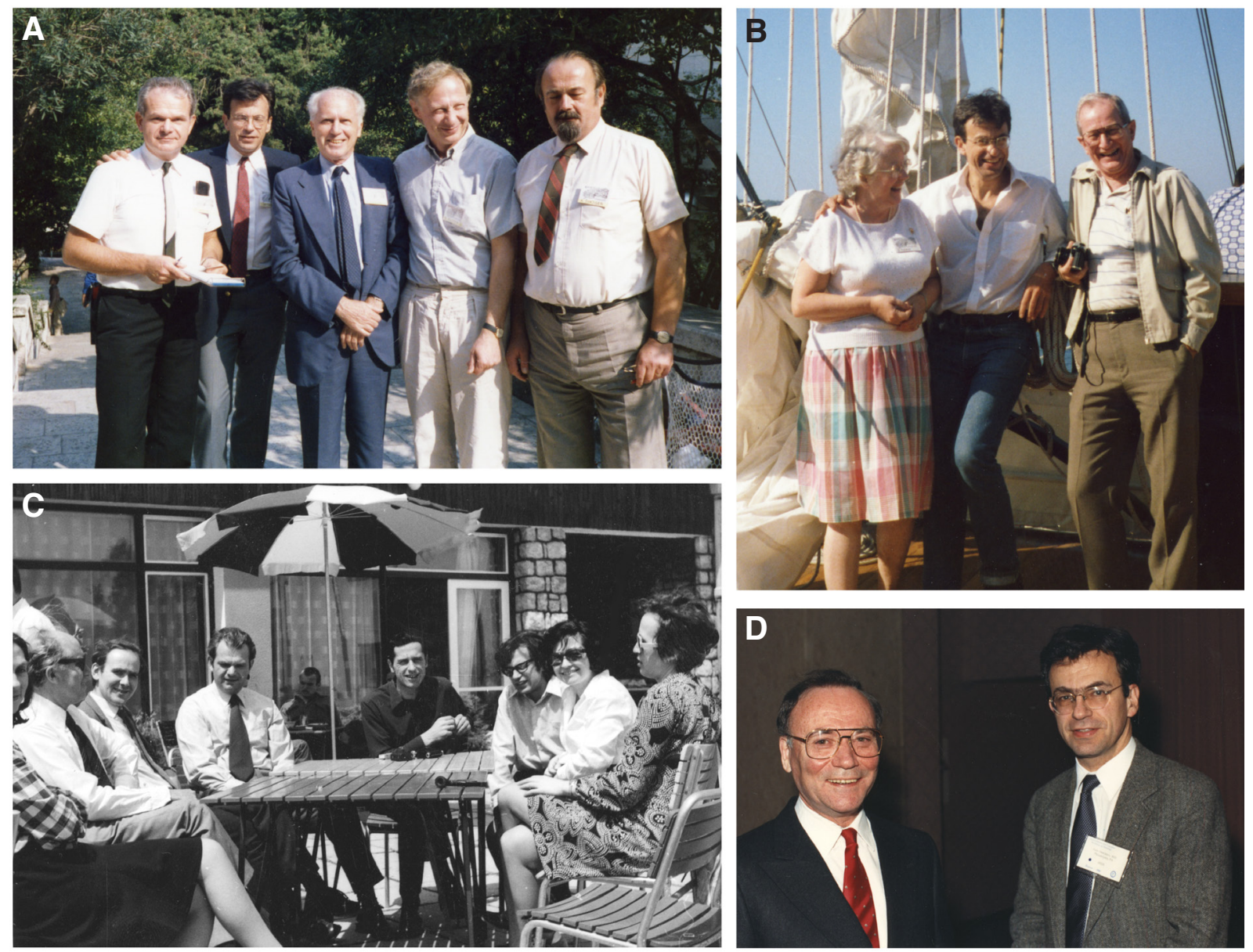

Fig. 1. Important scientists and clinicians in the academic life of Ivan Damjanov. (A) Professor Nikola Škreb with his former students. The core members of the Croatian School of Mammalian Embryology photographed at 1986 meeting in Dubrovnik, Croatia, honoring professor Škreb at the time of his retirement. From left to right: Draško Šerman, Ivan Damjanov, Nikola Škreb, Davor Solter and Anton Švajger. (B) Ivan Damjanov with G. Barry Pierce and his wife Donna on a boat near Dubrovnik, Croatia, 1986. (C) Meeting of European embryologists in Zagreb 1972. From left to right: Anne McLaren, Nikola Škreb, Richard Gardner, Draško Šerman, Andrzej Tarkowski, Ivan Damjanov, Božica Levak-Švajger and another meeting participant. (D) Ivan Damjanov with Emanuel Rubin, who was at that time Chairman and Gonzalo E. Aponte Professor of Pathology at the Thomas Jefferson University, Jefferson Medical College, Philadelphia, Pennsylvania. The two of them worked together in Philadelphia for 17 years, editing for the United States-Canadian Academy of Pathology, their major pathology journal Laboratory Investigation, and reorganized the teaching of pathology at Jefferson Medical College. 
The conditions in my country of birth were far from ideal, but nevertheless, for all practical purposes, I had a privileged life. My father was a veterinarian and owned a couple of small vineyards that he bought before the Second World War. He sold wine and thus we had additional income, which set us apart from our neighbors. We were considered well-off, if not rich, in comparison with others. My mother was a pharmacist, and although the communist government forced her to "donate her pharmacy to the people", basically confiscating it, she managed to have a small black market business of her own. She was making her own pain-killer concoctions, cough syrups, beauty creams and trinkets, selling all those items over the counter for extra income (and off the books). I still remember helping her in that state-owned pharmacy as she sold young women a "cream for day" and a "cream for night," whatever that was. It was the first money I earned for our family.

My parents were ideologically against the communists but they kept a low profile and tried to stay out of politics. They did not join the communist party but also did not criticize the regime, which allowed them to live a comfortable bourgeois life. For example, in our house we had live-in servants and a cook - my sister and I had even had German-speaking nannies. My sister and I were protected from the turmoil in the outside world and both of us had a wonderful childhood, more or less unaware of the political and social problems of other citizens and the overall poverty of the populace.

Things improved even more when my father decided to send me away from the small town where I was born (Subotica) to the big city where I attended the Classical Gymnasium, or high school (Zagreb). My father chose that particular school, which was founded by Jesuits in 1607, so that I would get the best possible humanistic education. He bought a house for me in Zagreb and sent me away with my grandmother in tow. My high school years in Zagreb were the best years of my life. Sports, movies, theater, my first loves, my fist encounter with literature, the classical world and philosophy--all that indelibly links me to Zagreb. As Rudyard Kipling said, "We've only one virginity to lose, and where we lost it there our hearts will be!" I married a woman from Zagreb, and we still have a house there. I visit Zagreb frequently and I still have dual, Croatian and USA, citizenship. Zagreb is Croatia's capital, a wonderful, vibrant city.

Going back to your question about life in former Yugoslavia, I am not exaggerating when I say that for me it was dreamlike. It is true that Yugoslavia was a communist country, but I perceived it as "communism with a human face." Above all, I cherish the education that I received there. By the end of high school, I spoke three foreign languages; I had mastered calculus, lectured on Freud's teaching, participated in debate clubs about education and ancient Greek philosophy, and even published lyric poetry. I had also traveled abroad, and by the age of 17 I had hitchhiked for three weeks through all of England, Scotland and Wales. Comparing myself with kids of my age from Western Europe, I realized that my education in Yugoslavia was first-class and that I had no reason to be ashamed of my origins. I did not feel deprived or handicapped. All of the positive experiences during my schooling gave me selfconfidence and encouraged me to look beyond the confines of the country of my birth. Thus I became an internationalist and equally at home in America and Europe. Up to this day I remain absolutely opposed to nationalism and tribalism, rigid ideologies of any stripe, dogma, and intolerance. I abhor "counting red blood cells," the colloquial phrase used in all the countries that came out of former Yugoslavia, as a synonym for determining whether you are Croat, Serb, Muslim or, God forbid, some unclassifiable "mongrel." It is maybe because of my Weltanschaung that I like so much the title of your journal.

\section{How did you become interested in biology and medicine and who kindled your interest in this area?}

With a strong background in psychology, which I acquired in high school by reading books by Freud, Adler and Jung, I entered medical school to become a psychiatrist. Today, I think that I would have been a horrible psychiatrist and it is best for everybody concerned, especially the patients, that soon after entering the clinics I gave up on my original career plan. Thereafter I began thinking about internal medicine. As a medical history buff I noticed that many internists have some pathology training. Thus, prior to entering internal medicine training, I thought that I should spend some time in pathology and "see how does the body look from inside." After graduation I therefore joined the pathology department and began doing autopsies. I became fascinated by microscopy and after three months of pathology I decided that I would remain in that specialty for the rest of my life. Up to this day, after more than 45 years of pathology, I still enjoy practicing it.

The above-mentioned Int J Dev Biol Special Issue on "Developmental Biology in Yugoslavia" was dedicated to the late Professor Nikola Škreb, the pioneer of mammalian developmental biology in your native country. I know he was very influential during your medical studies at your alma mater, the University of Zagreb. Why did you choose originally to be a pathologist and in what way did Prof. Škreb stimulate you towards basic scientific research?

As I said in my response to your previous question, I went into pathology by eliminating two clinical specialties. There was also another reason: I thought that by entering pathology I could also do basic laboratory research, and that brings me to professor Škreb (Fig. 1A), the most important teacher I ever had.

The story about professor Škreb is a long one but I will try to shorten it for this interview. It all began around the end of my freshman year of medical school. Those days, the professors at several Yugoslav medical schools decided to foster science and recruit medical students into scientific laboratories. To this end they encouraged medical students to work with them on scientific projects. They also organized yearly scientific medical student congresses. At these congresses the students were supposed to present to each other what they had accomplished by volunteering in research laboratories or in the clinics. It just so happened that the Second Congress of Medical Students of Yugoslavia took place in Zagreb in May of 1960. I decided to attend the basic science session. Since I was at the end of my first year I was hoping to understand at least something of those senior students' presentations. Unfortunately I did not understand much, but I was very much impressed by their talks. I even summoned the courage to ask a question after one of the presentations, and only later realized how stupid I must have sounded. The presentation was about the adverse effects of some drug on the developing rat fetus, and my question was: Could you please tell me what exactly is teratology?

After the session finished I approached the senior student who worked on that teratological study and told him that I would like to do something similar. He responded that he would introduce 
me to professor Škreb, with whom he did that study. By the way, I should mention that the student with whom I spoke that day was Suad Efendić. Suad became an internationally known diabetologist, a famous scientist in his own right, and a professor of internal medicine at the Karolinska Sjukhuset in Stockholm.

My introduction to professor Škreb at the beginning of my second year of medicine was quite memorable. Suad introduced me to him and soon thereafter the professor invited me to his office. I was scared stiff, because in those days students had no informal contact with professors; we were not supposed to talk to them, interfere with their all-important work, and "waste their time." Thus I was really surprised that professor Škreb was willing to talk with me. Furthermore, I was shocked beyond my wits when he offered me a chair in his office--those days if you spoke with professors you were always supposed to stand. The moment professor Škreb invited me to sit down in his office was my Rubicon, and I crossed it that day. I decided on the spot that I will become a scientist like him and I never regretted it.

During that time, you also started a long and lasting scientific relationship with your classmate Davor Solter, with whom you have enjoyed a fruitful collaboration for many years, as can be seen in the numerous papers you published together. How complementary are your different research approaches and points of view regarding biological and pathological development?

Davor Solter (Fig. 1A) is one week older than me, but his mother thought that he should enjoy a carefree childhood for as long as possible and delayed his entry into the first grade for one year. Accordingly, he graduated from high school one year later than me, and thus we are technically not actual classmates. We went to the same Classical gymnasium and knew each other informally from school and from participating in poetry-reading sessions in various literary clubs in Zagreb. We became friends at university and our friendship grew even more after I persuaded him to join me on a research project. I even tried to lure him into pathology, but he decided to stay with Professor Škreb. I went to America in 1967, but after two years of pathology training in Cleveland and New York City I returned to Zagreb in 1969 and started working with Solter and Škreb. A year later we published our first Nature paper on mouse teratocarcinomas (Solter et al., 1970) and continued working jointly at the interface between developmental biology and pathology until Davor and I finally moved to America for good. Davor and I continued finishing some old projects and collaborated later on new projects. Professor Škreb died in 1992.

The days with Davor Solter and Nikola Škreb in Zagreb belong to the most pleasurable period in my life. Initially Davor and I did not know much and in essence we learned everything by trial and error on our own. Furthermore, we did not have much money, the resources were paltry and the infrastructure for research almost nonexistent. Despite these circumstances we dreamed about "making it" (whatever that meant for us) and literally lived for science day in and day out. We did everything ourselves, including arranging the mating of mice and rats, isolating the embryos, transplanting them, staining the slides histochemically, printing the photographs for publication, writing the papers (in broken English!), typing them with carbon copies (Xerox machines were not available to us), etc. I still do not know how we managed to do it, but if you check on PubMed you will see that we published quite a few papers in reputable international journals. I always like to say: "It was not easy, but it was a lot of fun." You forget the primitive and even somewhat miserable conditions under which we worked, and all of the frustrations, but you remember the fun.

G. Barry Pierce (Fig. 1B) in Denver, Colorado, noticed our publications from that godforsaken little country called Yugoslavia. Barry was one of the pioneers in teratocarcinoma research (Pierce, 1967; Aréchaga, 1993). He was a very generous man and from our early days in science he became our great supporter and friend. Roy Stevens, another pioneer in this field (Stevens,1967), also responded to our papers and came all the way from Bar Harbor, Maine, to visit us in Zagreb. We talked about embryos and teratomas, had a few drinks and then started telling stories, some of which I still remember. Well-known developmental biologists like Richard Gardner and Anne McLaren came for an informal meeting from England, together with Andrzej Tarkowski from Poland (Fig. 1C). I could not believe my luck that all these famous scientists were coming to Zagreb and discussing developmental biology problems with us "greenhorns" as if we were professionally equal to them--of course we were not. We felt that we were slowly entering into the international scientific community.

Even today I remember a notice we saw about an international meeting on differentiation that was supposed to take place in Nice, France in 1971. Davor and I decided to write to the organizers telling them that we also would like to participate. Since we did not speak idiomatic English we did not know whether we should start our letter with the phrase, "We took the liberty to write to you" or "We took the freedom to write to you." In Croatian there is namely no difference between freedom and liberty and thus we chose "freedom." Barry Pierce told us later that he got our letter and recommended to the organizer to invite these "freedom-loving guys" (tongue firmly in cheek), vouching that we were O.K. Our presentation was delivered by Professor Škreb (Skreb et al., 1972).

Ever since then, Barry Pierce has been our great supporter and a good friend of the entire Zagreb group (Fig. 3). I owe Barry a lot and consider him my American scientific godfather. Many years later he asked me to take his position and replace him as the North American editor of the journal Differentiation, which was edited by Werner Franke from Heidelberg. Later on, as homage to G. Barry Pierce, Antonio Martinez-Hernandez and I edited a special issue of The International Journal of Developmental Biology as a multi-authored Festschrift devoted to him (Damjanov and Martinez-Hernandez, 1993).

Most of our contacts outside of Zagreb were with developmental biologists until one day we received a letter from the World Health Organization (WHO) in Lyon; V. Turusov, a Russian scientist working for the WHO who invited us to contribute a chapter for a pathology book that he was compiling on mouse tumors, signed it. Jokingly we referred to it as the "Mickey Mouse encyclopedia,"but needless to say, we were very flattered to be included as contributors. Dr. Turusov came to Zagreb and we wined and dined him for 2-3 days. The book with our chapter in it was published, almost as an afterthought and anticlimactically, a few years thereafter (Damjanov et al., 1979). In 1972 it nevertheless meant a lot to us, especially because it was a nod from pathologists working for the WHO. It seemed to us that the pathology part of our work was also getting some attention. We summarized our early work in a review published in a German pathology periodical (Damjanov and Solter, 1974). Our WHO book chapter has been long forgotten, 
but the 1974 review article still attracts the attention of our junior colleagues, and it is still cited.

Rupert A. Willis, in his well-known monograph The Borderland of Embryology and Pathology (1958), wrote "embryologists and pathologists have much to gain by a better knowledge of each other's subjects". As a good example of this, Martin Evans recognized in his Nobel Lecture of 2007 the important role in his discoveries played by G. Barry Pierce, who in 1964 showed that transplantation of a single embryonal carcinoma cell in vivo could result in a fully differentiated teratocarcinoma and unequivocally established the existence of pluripotent tumor stem cells, discoveries that paved the way for the isolation and culture of embryonic stem cells. How do you see the present relationships between Pathology, particularly neoplasia, and Developmental Biology?

I would extend Sir Martin Evans' thought and add that without a good understanding of embryology, one cannot fully understand pathology and vice versa. In this context you should only look at the life of G. Barry Pierce, who was a pathologist by training and a scientist by avocation. He was a true idol who showed me, and many others, that you could do science and still be a hospital pathologist. Both Barry and I considered RupertA. Willis as one of our forefathers, and spent our lives working on that magic borderland between normal and neoplastic development.

In the final analysis I would say that embryology and pathology have much more in common with one another than it appears on the surface (Figs. 2D and 4). I consider cancer just one of the possible developmental pathways that a normal embryonic cell can chose, and thus, somewhat facetiously, even achieve the eternal human dream of reaching immortality. As a pathologist I improved my practice by my understanding of developmental biology, and my knowledge of pathology has contributed something to the better understanding of developmental biology. After G. Barry Pierce retired, by default I became probably one of the best pathologists among embryologists, and one of the best embryologists among the pathologists. I lived most of my professional life in a Manichean manner, divided and sometimes even torn between developmental biology and pathology. It made me admire bridge-builders, and I always wished that one day somebody would call me pontifex,
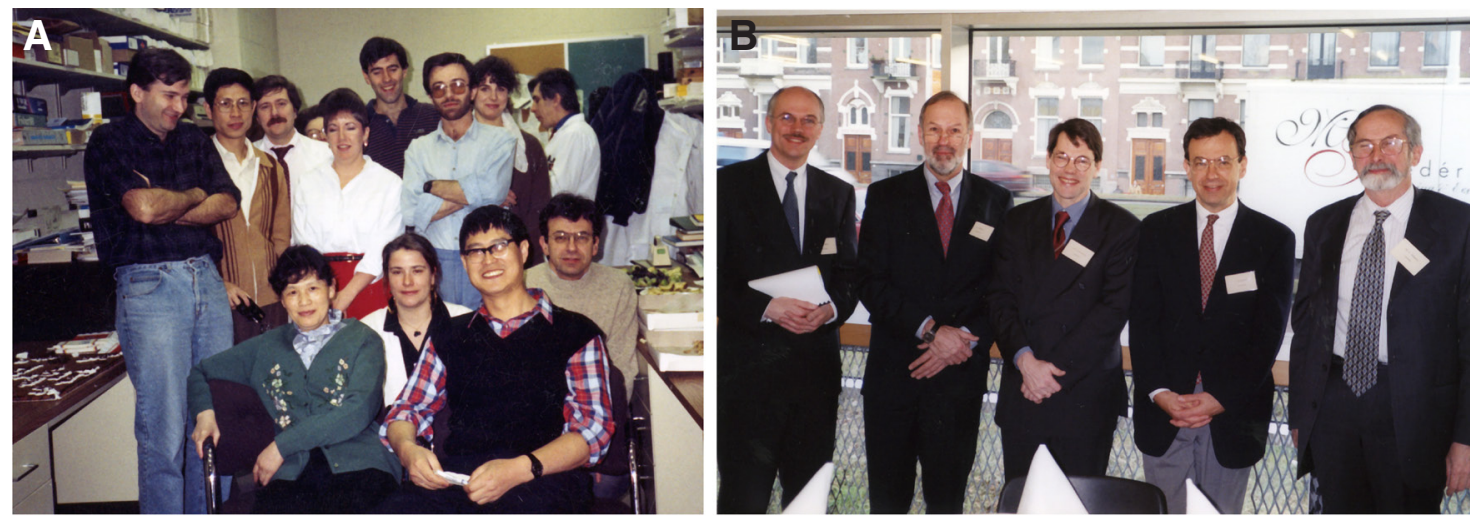
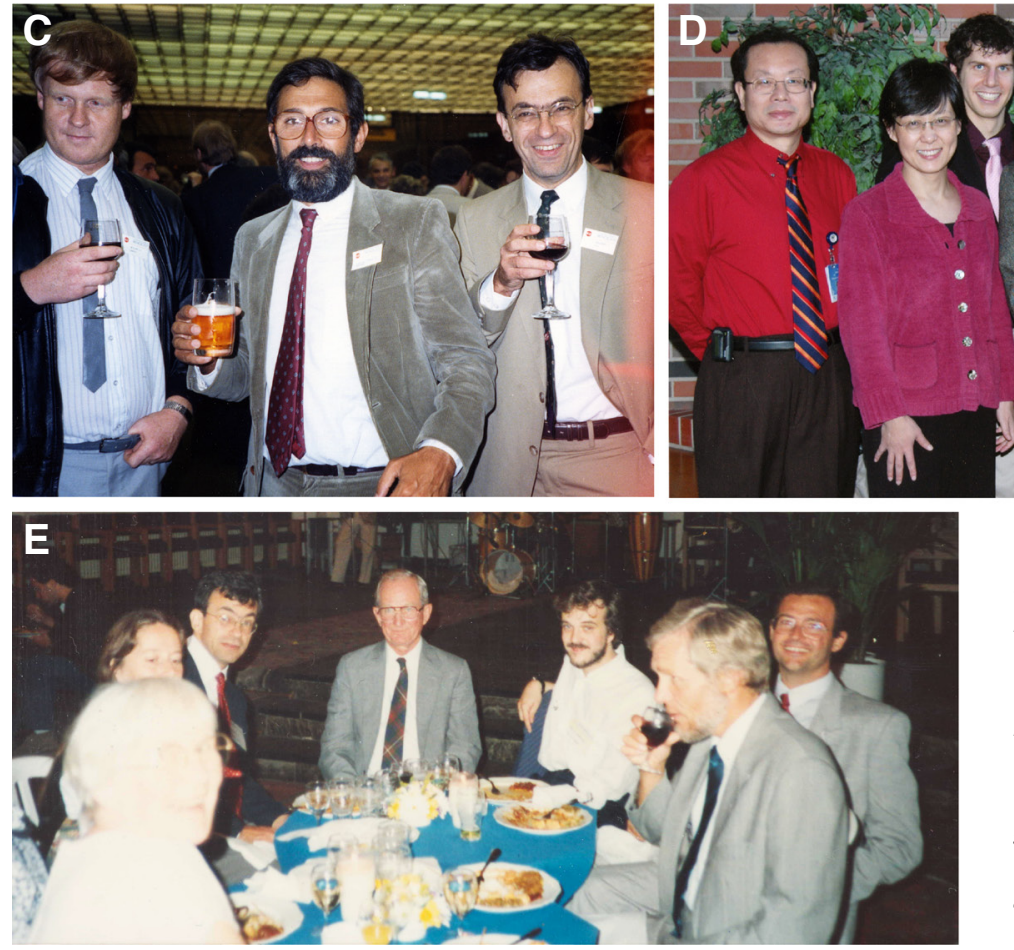

Fig. 2. Ivan Damjanov with collaborators and colleagues. (A) With his research team in a crowded laboratory at the Thomas Jefferson University, Philadelphia in 1991. (B) With J. Wolter Ooosterhuis and several other European scientists at the opening of the Josephine Neskens Institute of Pathology at the Erasmus University, Rotterdam. Wolter became the first chairman of the new Insitute in Rotterdam, which was built mostly through his initiative. (C) At the European Congress of Pathology in Prague, 1987. Ivan Damjanov joined the European Society of Pathology in 1979, served on the editorial board of its journal (Virchows Archive), and attended de rigueur almost all biannual congresses organized by the society. Here he is shown with Jahn Nesland of Oslo, Norway and Manuel Sobrinho-Simões of Porto, Portugal, two important friends who helped build international bridges. (D) With his colleagues from the Department of Pathology at the University of Kansas School of Medicine, who helped him publish the Atlas of Histopathology for medical students in 2011. (E) With a group of human pathologists trained in mammalian embryology or vice versa, including G. Barry Pierce, Eero Lehtonen and Juan Aréchaga, at the 1989 meeting of the International Society of Developmentral Biologists in Utrecht, The Netherlands. 
using the Latin term for bridge builder. In ancient Rome, Pontifex Maximus was the title of the highest ranked priest, because after death he led souls across the imaginary bridge connecting this world to the other one high above. My bridges were not so lofty but were designed as spans between embryology and pathology, pathology and clinical medicine, America and Europe, and--to remind you of the carnage in my old country--the Serbs and the Croats. I am not sure how many bridges will remain after I cross over the one governed by the Pontifex Maximus, but I enjoyed imaginary bridge building, which has been one of the major preoccupation of my life.

Your 1970 Nature paper, authored with Nikola Škreb and Davor Solter, on the transplantation of mouse embryos at the gastrulation stage under the kidney capsule, with previous contributions by Leroy Stevens and Barry Pierce, initiated a fruitful period of research on experimental teratocarcinomas. Could you summarize the main contributions of the Croatian School of Mammalian Embryology to this field?

I love your question, especially since you used the term Croatian School of Mammalian Embryology (Figs. 1 A,C). I am a sentimental guy but also a team player and I hope that future generations will remember that sometime during the 20th century there was indeed a true school of developmental biology in that little country of 4.5 million people. Etymologically the word school is derived from the Greek word scholé, which also means lecture, discussion, and leisure. In the Zagreb of my youth we did not attend too many lectures but we definitely had a lot of discussions, and all the leisure time we had we invested into science. The dictionary says that scholé is derived from echein, which in Greek means to have or to hold. We did not have much, but whatever we achieved we held onto ferociously, always prepared to use it for the next step of our endeavors. The group spirit, the interaction and cross-pollination that took place then and there was something that cannot be described, but as a former participant I would dare say that it was magic, which happens only in a true scholé.

I still do not know how it was possible that we all got together at the same time and the same place. There is no doubt that the

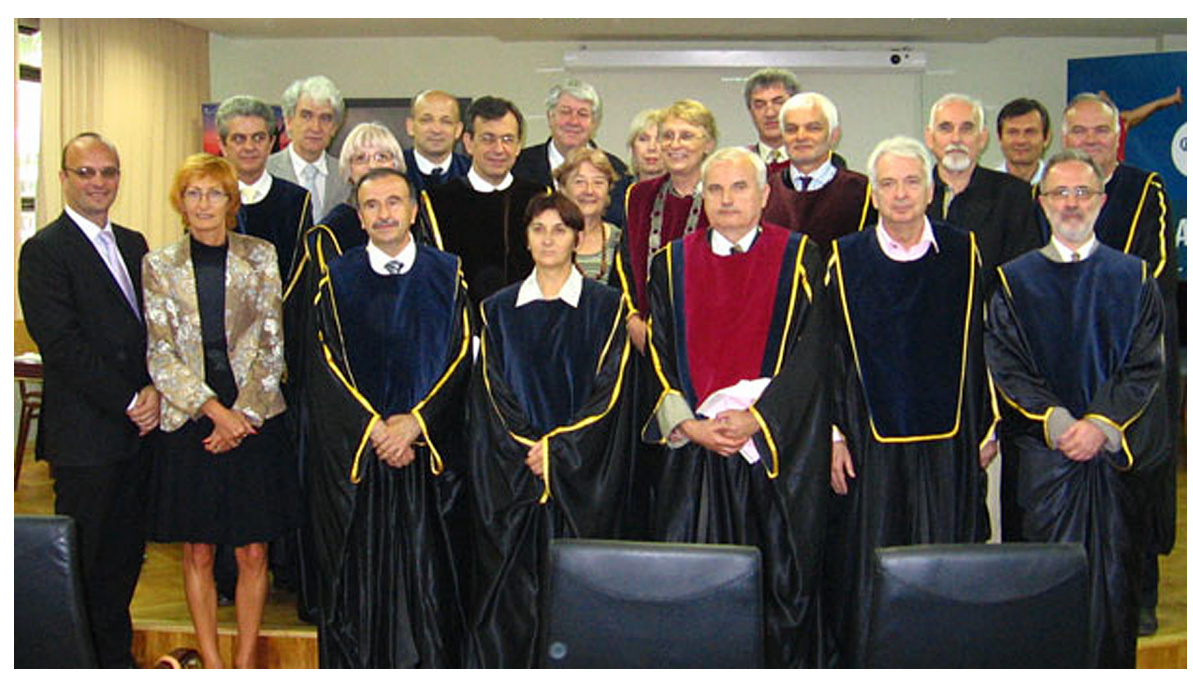

Fig. 3. Ceremony at the University of Novi Sad, Serbia, where Ivan Damjanov received an honorary doctorate degree (Doctor Honoris Causa) in 2008. This honor meant a lot to him because he was born $100 \mathrm{~km}$ North of Novi Sad in the province of Vojvodina, a part of former Yugoslavia, as well as the former Austro-Hungarian Empire. "grain of sand that formed the core of the pearl," the main catalyst and the spiritus movens, was professor Škreb (Fig. 4). His first students Božica Levak-Švajger and Anton Švajger expanded the base, which he started basically from nothing. Davor Solter, who had a unique understanding of developmental biology and a special insight, contributed the most to our group effort, and later on he achieved the greatest recognition in the scientific world. My contributions were maybe not so great, but I was a good foot soldier, and one of the cogwheels that kept our scientific machine moving. I was a true believer in our mission, and I liked to dream about "making a difference." I like to joke about my "dreams of greatness" by saying that my greatest contribution to science was persuading Davor Solter to enter developmental biology.

From a subjective point of view it is difficult to say what was the greatest contribution of the Croatian school of embryology. Most likely, it was our emphasis on the study of the implantation stage mammalian embryos, a topic that was relatively neglected by previous embryologists. The link between the normal and neoplastic development that emerged from our studies led to a major paradigm shift and opened new vistas that ultimately ushered the era of embryonic stem cells, both murine and human, transgenic mice and pluripotent stem cells in normal and neoplastic development. We were obviously not alone, and many others since have advanced the entire field in a more significant manner, but still I hope that our contributions will remain recorded somewhere, and possibly even revisited. Upon coming to America I tried my best to continue along the same lines of research, which was not easy due to my increasing obligations in hospital pathology and teaching. Still I remained funded by $\mathrm{NIH}$ for almost 20 years and kept the laboratory in Philadelphia alive (Fig. 2A).

Let us now get deeper into the developmental biology of the murine egg cylinder, an embryonic stage in which cell pluripotentiality begins to be lost. What are the main questions that still need to be answered about this important developmental period and what is its potential interest for pathologists?

We know that the early post-implantation stages of embryogenesis are important because during this time the embryonic cells lose their pluripotency (Škreb et al., 1991). Most of these data are derived from the study of murine embryos, and I hope that sometimes in the not-so-distant-future human models will be developed paralleling those in experimental animals. I would also like to know how embryonic cells lose their pluripotency or retain it, or become malignant. Those days we were talking about a critical "point of no return," but modern science indicates that many of the phenomena considered previously as irreversible can be reversed. All these events must be mapped in terms of molecular biology, and I do not think that we will need to wait long for that to be realized.

As a pathologist I would like to identify the developmental stage of the human embryo at which the cells still can form embryonal carcinoma. How can we transform normal embryonic cells into embryonal carcinoma cells that then assume the role of malignant stem cells of tera- 
tocarcinoma? There are currently so many embryo-derived human embryonic stem cells, but are they all developmentally equivalent? To which stage of human embryogenesis do they correspond? Some of them will become malignant and transform into embryonal carcinoma. We must learn to transform human embryonic stem cells into malignant embryonal carcinoma cells at will and thus fully elucidate this aspect of carcinogenesis which probably plays a role in the formation of testicular and ovarian germ cell tumors.

Please, tell us about your personal contributions to understanding the origin of yolk sac carcinomas and the importance of the experimental teratocarcinomas derived from transplanted embryos in this regard.

In humans, yolk sac carcinoma is a relatively rare tumor. G. Barry Pierce was the first to recognize a murine variant of that tumor and he also showed that its cells correspond to the parietal yolk sac (PYS) cells in the mouse embryo (Pierce etal., 1962). The tumor that Barry studied was derived from retransplantable murine teratocarcinomas, which he obtained from L. C. Stevens. Professor Škreb discovered that normal rat PYS transplanted to extrauterine sites can give rise to similar tumors, and we developed a rat model of PYS carcinoma (Damjanov et al., 1977). There must be something in the parietal yolk sac that makes those cells "immortal," allowing them to proliferate and form tumors if transplanted to extrauterine sites. Unfortunately my attempts to obtain funds to study the reasons for the "immortality" of extraembryonic cell lines were all unsuccessful and finally I gave up. Barry noticed that the PYS tumor secretes huge amounts of basement membrane material (Pierce et al., 1962). Many major basement membrane components were isolated from murine PYS tumors (Damjanov et al., 1990).

Human teratomas of the ovary are frequent and normally benign, but human teratomas of the testis are less frequent and generally malignant. On the other hand, animal teratomas occur at a low frequency and they are habitually benign. For these reasons, they are not a good model system for these tumors. Are there scientific explanations for these curious differences?

Your statement is correct but I do not know why human teratomas of the ovary are more common than germ cell tumors of the testis. Ovarian teratomas develop most likely from parthenogenetically activated oocytes (Fig. 5 A-D). Stevens and Varnum (1973) have described the sequence of events leading to formation of ovarian teratomas from spontaneous peripubertal parthenogenetic activation of oocytes in LT mice (Fig. $5 \mathrm{~A}$ ). This mouse is an excellent model for studying formation of ovarian teratomas. Even though Stevens has shown that testicular teratomas and teratocarcinomas can be produced from fetal testes (Stevens, 1967), there are no veritable animals models of human post-pubertal testicular teratocarcinomas. It would be reasonable to postulate that the testicular germ cells could be activated in a process similar to parthenogenesis in the ovary, but we still do not know how the male germ cells are activated. Likewise, we do not know why most germ cell tumors of the testis are malignant in contrast to most human ovarian germ cells tumors, which are in over $95 \%$ of all cases benign teratomas.
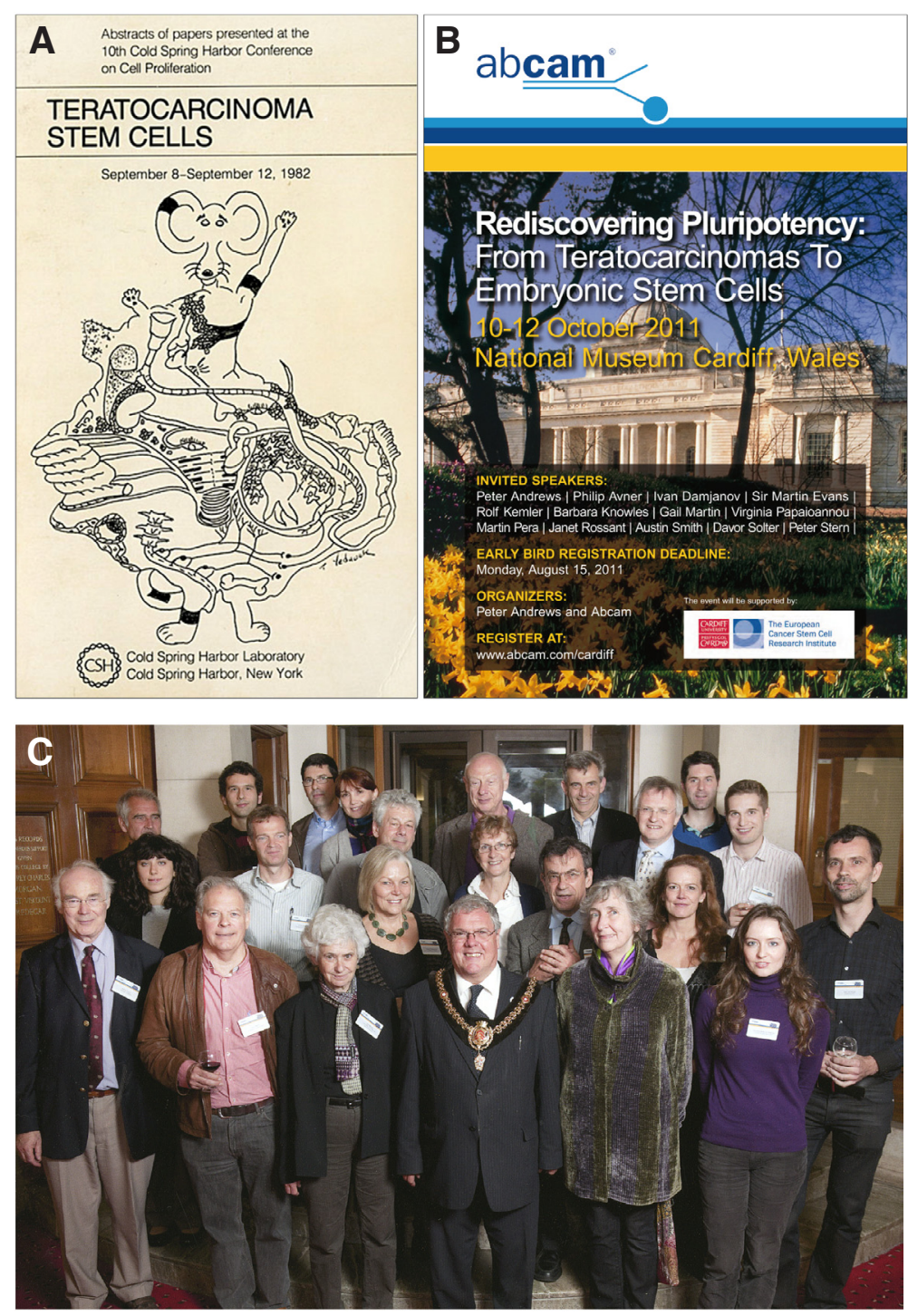

Fig. 4. Two important meetings that brought together molecular biologists, developmental biologists and pathologists to discuss in depth the biology of teratomas and pluripotent stem cells. (A) Front page of the abstract booklet of the "Teratocarcinoma Stem Cells" meeting in Cold Spring Harbor Laboratory, New York, in 1982. (B) Poster of the Cardiff meeting on "Rediscovering Pluripotency: from Teratocarcinomas to Embryonic Stem Cells" in 2011, organized by Peter Andrews, Abcam and The European Cancer Stem Cell Research Institute. (C) Group photograph of the speakers at the latter meeting, with Ivan Damjanovamong them.

Which cells are the progenitors of human ovarian teratomas?

Most textbooks state that teratomas are of germ cell origin, and several cytogenetic studies of these tumors support that concept. For example Surti et al., (1990) have studied cytogenetically over one hundred ovarian teratomas and concluded that $65 \%$ of teratomas are derived from a single germ cell after meiosis, and failure of meiosis II or endoreduplication of a mature ovum. The remaining $35 \%$ of tumors result from failure of meiosis I or mitotic division of premeiotic germ cells. The pathogenesis of teratomatous components of malignant mixed germ cell tumors of the ovary seems to differ from that of benign teratomas (Poulos et al., 2006). This leaves a lot of room for speculation about the pathogenesis of teratoid tumors in the ovary. The issue became even more complex after 
the discovery of ovarian stem cells and their peculiar niche in the ovary of adult women (Bukovski, 2011). Recent data also indicate that some germ cells could be originating from the ovarian surface epithelium (Virant-Klun et al., 2009).

\section{Does parthenogenesis play a role in the pathogenesis of ovarian teratomas?}

Since the pioneering work of Stevens and Varnum (1974) there have been several studies confirming the importance parthenogenesis as the initiating event leading to the formation of teratomas in mice (Hannesdottir et al., 2012). Techniques for parthenogenetic activation of human oocytes have been developed, although some oocytes become activated even on their own. Parthenogentically activated oocytes can serve as a source of pluripotent stem cells which have many if not all the features of embryonic stem cells obtained from embryos (Turovets etal., 2011). These studies provide very strong support to the hypothesis linking ovarian teratomas to parthenogenetical activation of ovarian germ cells.

\section{Why are there extragonadal teratomas?}

Extragonadal teratomas (Fig. 5D) develop most likely from germ cells that have been misplaced during development. Human primordial germ cells originate in the yolk sac, an extraembryonic

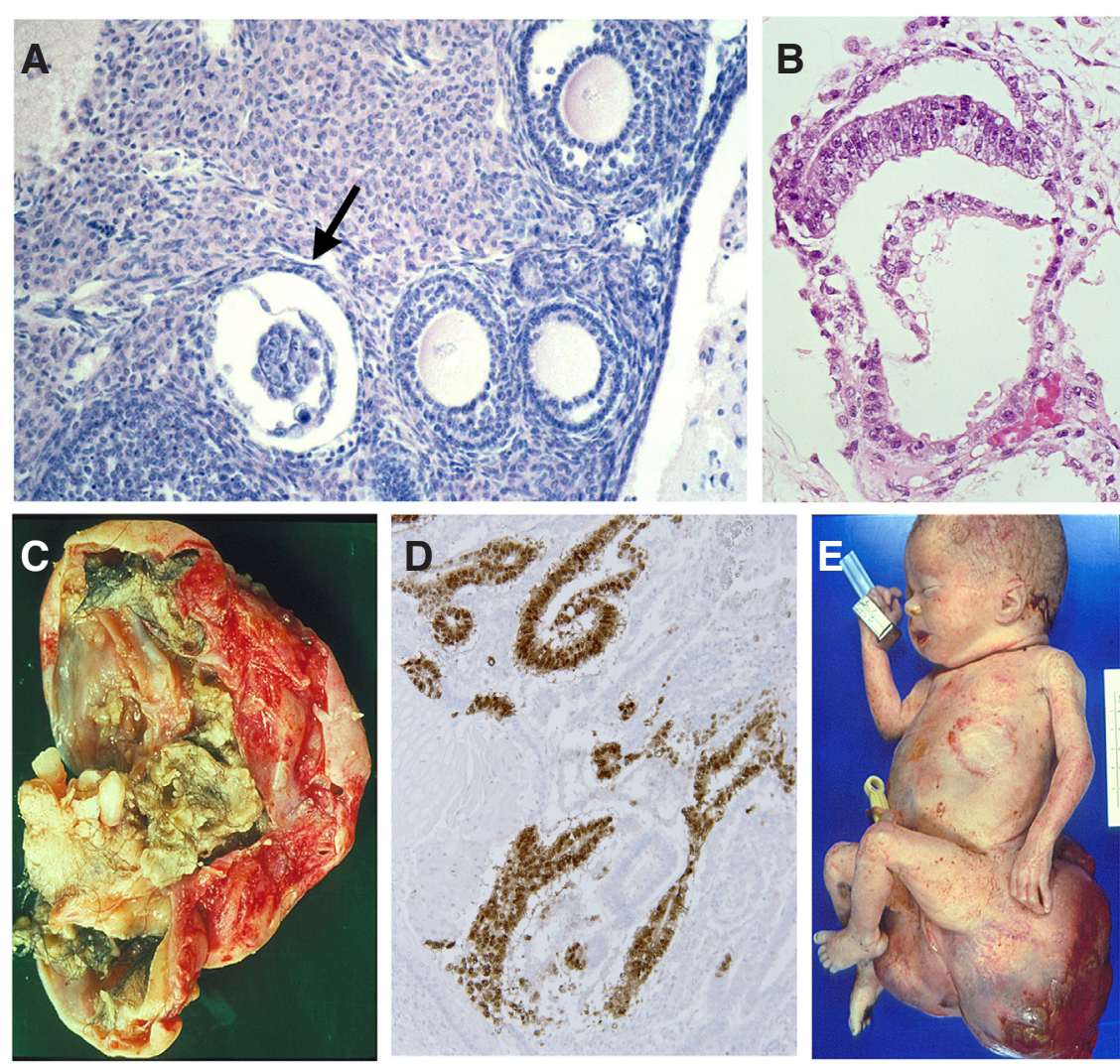

Fig. 5. Pathological images of female teratomas. (A) Parthenogenetic activation of oocytes in the ovary of Leiter (LT) mice results in the formation of preimplantation stage embryos. The arrow shows a blastocyst stage embryo. (B) An embryoid body from a teratocarcinoma has a remarkable resemblance to an early stage human postimplantation embryo. (C) Teratoma of the ovary with hair and teeth that are readily recognized on the inside cavitary portion of the tumor. (D) Antibody to OCT3/4 reacts selectively with the nuclei of embryonal carcinoma cells in a human teratocarcinoma. (E) Congenital extragonadal teratoma originating from the sacrococcygeal part of a newborn female baby. structure that involutes after it has nurtured the primitive precursors of germ cells and hematopoietic cells. Primordial germ cells enter into the developing embryo through the midline and then migrate laterally into the genital ridges on the posterior side of the coelomic cavity. Some primordial germ cells will by chance go astray and remain in the midline or migrate through the midline into the anterio brain and the pineal gland. These displaced germ cells are most likely the precursors of extragonadal teratomas, which are usually malignant. Some of the sacral teratomas could also represent resiof a twin (like a pygomele) that has not separated completely from the surviving twin sibling, into whose body it was incorporated. Teratomas produced in mice from embryos transplanted to extrauterine sites are a good replica of these extragonadal teratomas and teratocarcinomas (Damjanov and Solter, 1974).

\section{The terminology and classification of human, animal and ex- perimental germinal tumors are sometimes very confusing. Could you throw some light on this matter?}

The terminology of human and animal germ cell tumors is confusing to say the least. Under pressure from urologic oncologists, pathologists in the USA have adopted a simplistic approach and divide the common post-pubertal germ cell tumors into two major groups: seminomas and non-seminomas, which are also known as nonseminomatous germ cell tumors (NSGCT). The latter group comprises embryonal carcinomas, yolk sac carcinomas, choriocarcinomas, and malignant mixed germ cell tumors, which could also be called malignant teratomas or teratocarcinomas. For some reasons that I do not understand, present surgical pathologists and urologists have not generally accepted the historic term teratocarcinoma, even though it has been widely used in experimental pathology. For clinical purposes tumors that are not seminomas are diagnosed clinically as NSGCT and the pathologist then usually lists its components stating that the tumor contains embryonal carcinoma and teratoma elements, with occasional admixture of choriocarcinoma or yolk sac carcinoma components.

In mice there are no seminomas and thus the term NSGCT would be a nonsensical non-starter. Teratoid tumors of mice are classified either as benign teratomas or malignant teratocarcinomas. Teratomas are composed of somatic tissues that have a limited propensity for growth and are clinically benign. Teratocarcinoma is composed of somatic tissues, but also contain malignant stem cells, called embryonal carcinoma (EC) cells. EC cells are immortal malignant cells that can be transplanted from one mouse to another or cultured in vitro. They can differentiate into somatic tissue, which are biologically benign. By eliminating EC cells from teratocarcinoma with chemotherapy, one may transform a malignant teratocarcinoma into a benign teratoma, i.e., cure it the same way as the chemotherapy can cure human NSGCT by eliminating the malignant stems cells, the EC cells.

In my opinion, the murine tumor terminology 


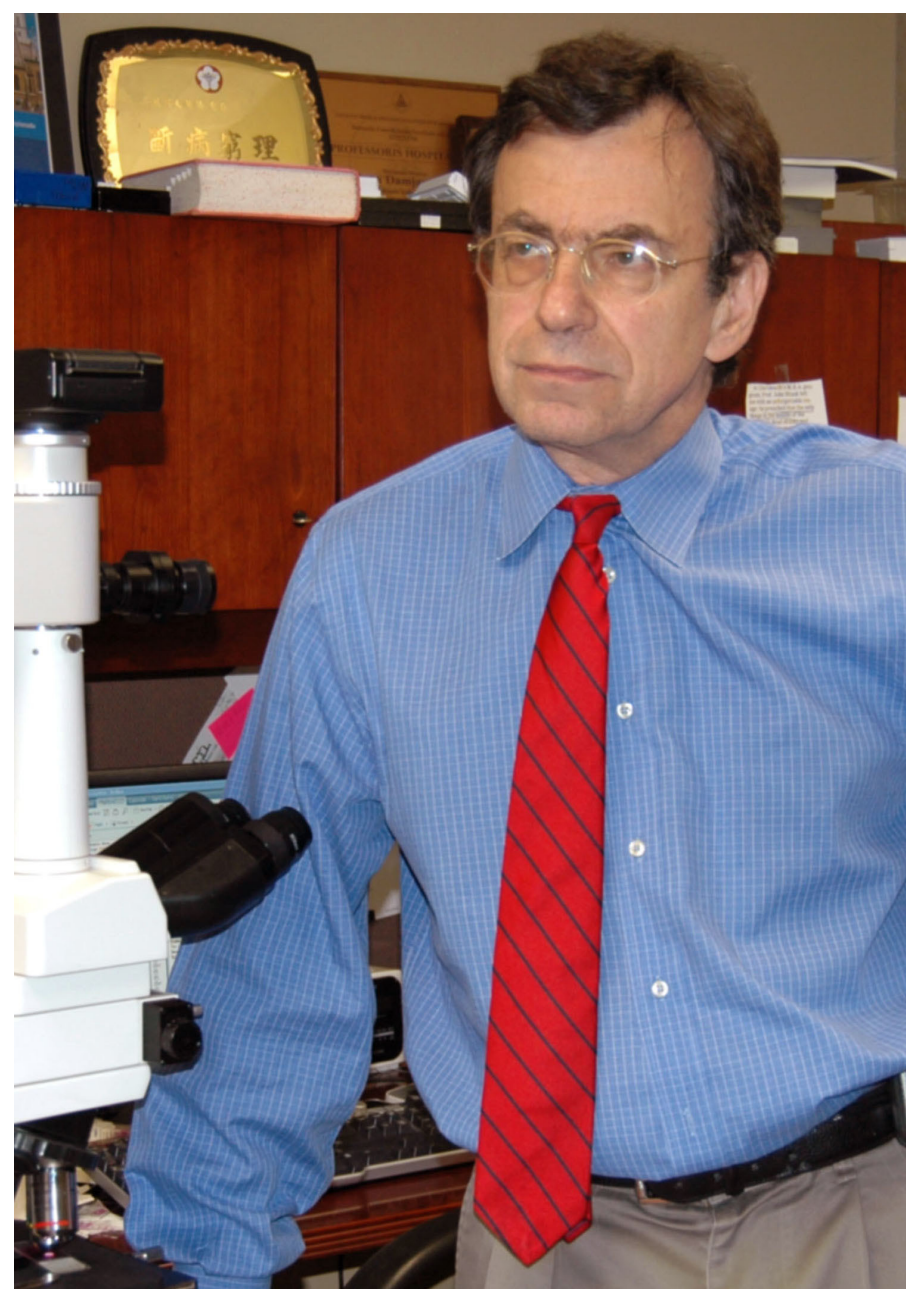

Fig. 6. Ivan Damjanov (MD-PhD), Professor of Pathology, photographed in 2009 in his office in the Department of Pathology at the University of Kansas School of Medicine, Kansas City, Kansas (USA).

used by experimental scientist is much simpler than the clinical terminology currently in use in the USA. On the other hand, I do not think that the clinical terminology will change; especially since the urologic oncologist find it useful. I would nevertheless insist that we apply the "murine terminology" to the study of xenografts produced from human embryonic stem cells injected into immunocompromised mice. Normal embryonic stem cells produce teratomas; embryonic stem cells that have become malignant produce teratocarcinomas (Aréchaga, 2011), which can be recognized by their malignant stem cells, corresponding to embryonal carcinoma cells (Damjanov and Andrews, 2008). To repeat this very important point, we suggest that xenografts composed of somatic tissue be classified as teratomas. Those xenografts that consist of somatic tissue but also contain embryonal carcinoma like stem cells should be called teratocarcinoma. Embryonic stem cells that produce malignant teratocarcinomas in xenografts should not be used for cell therapy and should not be injected under any circumstances into human beings.

How can the study of tumor biology be a source of knowledge about normal embryogenesis and how can an understanding of normal development and cell differentiation processes enhance our comprehension of the mechanisms and therapeutics of cancer?

The study of murine teratocarcinomas has taught us a lot about normal embryogenesis (Fig. 4). As mentioned before, Pierce, et al., (1962) have elegantly shown that the cells of the PYS carcinoma produce basement membrane-like material, which is equivalent to the so-called Reichert membrane in the early postimplantation stages of the mouse embryo. Surface antigens found on the mouse EC cells are equivalent to those on the normal embryonic cells (Solter and Knowles, 1976), and the differentiation of EC cells parallels the differentiation of normal embryonic cells (Damjanov, 1993). Brinster (Brinster,1974; Aréchaga, 1978) has injected murine EC cells into the blastocyst and shown that these malignant cells can lose their malignancy and incorporate into the developing embryo, successfully interacting with normal embryonic cells of the same developmental stage. Numerous other examples could be given in response to your question, some of which can be found in Solter's comprehensive review (2006), which provides a panoramic overview of these intriguing issues.

The fact that the malignant EC cells can differentiate into benign derivatives has been observed not only in mice teratocarcinomas but also in malignant human germ cell tumors. Embryonal carcinoma cells found in NSGCT may metastasize to lymph nodes and other organs, and if untreated will ultimately kill the host. However, with appropriate modern chemotherapy, metastatic EC cells can be arrested in their growth, killed or directed to differentiate into nonproliferating benign tissue. The high cure rate of human NSGCT is in part based on the potency of cytotoxic drugs, and in part related to the differentiation of malignant EC cells into non-proliferating benign somatic tissues. Treated malignant NSGCT in which the EC cell have been directed to differentiate into benign tissue is a prime example of the effectiveness of the so-called differentiation therapy.

I do not want to finish this interview without asking you about an aspect that impresses me very much in your brilliant academic biography; together with your passionate interest in scientific research and surgical pathology, you have an outstanding dedication and success in different aspects of teaching Pathology, something that is not very usual these days in Academia. Tell us about the importance of a proper balance between research, professional practice and educational activities for a correct university dedication at Medical Schools.

As a medical student in Zagreb I became acquainted with the work of Abraham Flexner, whose efforts to modernize the medical school education in the USA led to the publication of the eponymous report in 1910. The ideal academic physician described in Flexner's report was envisioned to divide his time into three equally important activities. He (those days there were few shes!) was supposed to be $1 / 3$ clinician, 1/3 researcher and 1/3 educator. Early in my professional life I decided to become a Flexnerian academic physician and for the rest of my life I tried to live up to that ideal. Unfortunately, the contemporary pace of life and the hectic demands of modern medical practice have not always allowed me to be a Flexnerian tripartite academician. Accordingly, during various parts of my career I was more concerned with research or clinical work, but irrespective of my main emphasis I have always participated in the teaching activities expected from me. I have also spent considerable time writing textbooks, believing, rightly or wrongly, that 
the written word will have a more lasting effect and reach many more students than I could ever do through ephemeral lectures.

I was lucky to have met during my residency training Dr. Emanuel Rubin (Fig. 1D), a research-oriented physician and pathologist. When Manny moved to Philadelphia in 1977 I joined him to help him build a Flexnerian department of pathology at the Hahnemann Medical College (Fig. 6). After 8 years, we moved to Thomas Jefferson University in Philadelphia, and rebuilt the pathology department along the same lines. Manny always supported me and allowed me to remain Flexnerian to the end of my Philadelphia period. My first post-doctoral fellow in Philadelphia, J. Wolter Oosterhuis (Fig. 2B) was also a pathologist, who later became Chairman of the Department of Pathology at the Erasmus University in Rotterdam (Netherlands). His research group made major contributions to the understanding of human testicular germ cell tumors (Oosterhuis and Looijenga, 2005).

Could I have achieved more in science by concentrating more on research and spending less time teaching students or writing books or building international bridges across the Atlantic? Unfortunately we have only one life to live, and a properly controlled experiment won't be able to be performed, at least not in my case. Thus, I will never know the answer to this question, which remains rhetorical. Even after a recent meeting in Cardiff, Wales, UK (Figs. 2B and $4 \mathrm{C}$ ) where I met some of my old friends from my "teratocarcinoma days", I do not know the answer. Still, I like to console myself by quoting the American sports journalist and poet Grantland Rice: "For when the One Great Scorer comes to mark against your name, He marks - not that you won or lost - but how you played the Game". I did it the best way I knew, but whether it was good enough I leave it to the One Great Scorer to decide!

\section{Acknowledgements}

This work was supported by Grants from the Spanish Ministry of Economy and Competitivity (SAF2012-39773), Basque Regional Government (IT560-10) and the SPRI/Saiotek program of the Basque Society for Industrial Restructuring and Promotion (S-OA11UN001). Milena Damjanov contributed to the editing of the article. Figures $5 B$ and $5 C$ were reproduced from the book I.Damjanov: Pathology for the Health Professions, 4th edition (2012), Elsevier Saunders, Philadelphia, with the kind written permission of the Publisher.

\section{References}

ARÉCHAGA J (1993) On the boundary between development and neoplasia- An interview with Professor G. Barry Pierce. Int J Dev Biol 37: 5-16.

ARÉCHAGA J (1998) Embryo culture, stem cells and experimental modification of the embryonic genome- An interview with Professor Ralph L. Brinster. Int J Dev Biol 42: 861-877.

BRINSTER R L (1974) The effect of cells transferred into the mouse blastocyst on subsequent development. J Exp Med 104: 1049-1056.

BUKOVSKY A (2011) Ovarian stem cell niche and follicular renewal in mammals. Anat Rec (Hoboken) 294: 1284-1306.

DAMJANOV A, WEWER U M, TUMA B and DAMJANOV I (1990) Basement membrane components secreted by mouse yolk sac carcinoma cell lines. Differentiation 45: 84-95.

DAMJANOV I (1993) Teratocarcinoma: neoplastic lessons about normal embryogenesis. Int J Dev Biol 37: 39-46.

DAMJANOV I and ANDREWS P W (2007) The terminology of teratocarcinomas and teratomas. Nat Biotechnol 25: 1212.

DAMJANOV I and MARTINEZ-HERNANDEZ A, Eds. (1993) Developmental Aspect of Neoplasia. Int J Dev Biol 37: 1-243.

DAMJANOV I, ŠKREB N and SELL S (1977) Origin of embryo-derived yolk sac carcinoma. Int J Cancer 19: 526-530.

DAMJANOV I and SOLTER D (1974) Experimental teratoma. Curr Top Pathol 59: 69-129.

DAMJANOV I, SOLTER D and ŠKREB N (1979) Teratoma. In: Pathology of Tumors in Laboratory Animals, Vol 2: Tumors of the Mouse (Ed. V.S.Turusov) WHO, IARC, Lyon pp. 665-669.

HANNESDOTTIR L, DASCHIL N, PHILLIP S, TYMOSZUK P, MULLER-HOLZNER E, KLIMA G, VERDOFER I and DOPPLER W (2012) MMTV-neu mice deficient in STAT1 are susceptible to develop ovarian teratomas. Int J Dev Biol 56: 279-283.

MULNARD J (1992) The Brussels School of Embryology. Int J Dev Biol 36: 17-24.

OOSTERHUIS JW and LOOIJENGA LH (2005) Testicular germ-cell tumours in a broader perspective. Nat Rev Cancer. 5: 210-222.

PIERCE G B (1967) Teratocarcinoma: model for a developmental concept of cancer. Curr Top Dev Biol 2: 223-246.

PIERCE G B, SHIKES R and FINK L M (1978) Cancer. A problem of Developmental Biology. Prentice-Hall Foundation of Developmental Biology Series (Ed. C L Markert), Prentice-Hall, Inc, Englewood Cliffs, New Jersey.

PIERCE G B, MIDGLEY A R, SRI RAM J and FELDMAN J D (1962) Parietal yolk sac carcinoma: clue to the histogenesis of Reichert's membrane of the mouse embryo. Am J Pathol 41: 549-566.

POULOS C, CHENG L, ZHANG S, GERSELL D J and ULBRIGHT T M (2006) Analysis of ovarian teratomas for isochromosome 12p: evidence supporting a dual histogenetic pathway for teratomatous elements. Mod Pathol 19: 766-771.

ŠERMAN D (1991) Why the mammalian embryo?-An interview with Professor Nikola Skreb. Int J Dev Biol 35: 149-154.

SILVÁN U, DÍEZ-TORRE A, ANDRADE R, ARLUZEA J, SILIÓ M and ARÉCHAGAJ (2011) Embryonic stem cell transplantation into seminiferous tubules. An in vivo model for invasive non-seminoma germ cell tumors of the testis. Cell Transplant 20: $637-642$.

ŠKREB N, DAMJANOV I and SOLTER D (1972) Teratomas and teratocarcinomas derived from rodent egg shields. In: Cell Differentiation (Eds. R Marris, P Alin and D Viza) Munksgaard,Copenhagen pp.151-155.

ŠKREB N, SOLTER D and DAMJANOV I(1991) Developmental biology of the murine egg cylinder. Int J Dev Biol 35: 161-176.

SOLTER D (2006). From teratocarcinomas to embryonic stem cells and beyond: a history of embryonic stem cell research. Nat Rev Genet 7: 319-327.

SOLTER D and KNOWLES B B(1978) Monoclonal antibody defining a stage-specific mouse embryonic antigen (SSEA-1). Proc Natl Acad Sci USA 75: 5565-5569.

SOLTER D, ŠKREB N and DAMJANOV I (1970). Extrauterine growth of mouse egg cylinders results in malignant teratoma. Nature 227: 503-504.

STEVENS L C (1967) The biology of teratomas. Adv Morphog 6: 1-31.

STEVENS L C and VARNUM D S (1974)The development of teratomas from parthenogenetically activated ovarian mouse eggs. Dev Biol 37: 369-380.

SURTI U, HOFFNER L, CHAKRAVARTI A and FERRELL R E (1990). Genetics and biology of ovarian teratomas. I. Cytogenetic analysis and mechanism of origin. Am J Hum Genet 47: 635-643.

ŠVAJGER A, Ed. (1991) Developmental Biology in Yugoslavia. Int J Dev Biol 35: 145-365.

ŠVAJGERA(1991) Tradition and present state of developmental biology in Yugoslavia. Int J Dev Biol 35: 155-159.

TUROVETS N, SEMECHKIN A, KUZMICHEVE L, JANUS J, AGAPOVA L and REVAZOVAE (2011). Derivation of human parthenogenetic stem cell lines. Methods Mol Biol 767: 37-54.

VIRANT-KLUN I, ROZMAN P, CVJETICANINB, VRTACNIK-BOKALE, NOVAKOVIC S, RÜLICKE T, DOVC P and MEDEN-VRTOVEC H (2009) Parthenogenetic embryo-like structures in the human ovarian surface epithelium cell culture in postmenopausal women with no naturally present follicles and oocytes. Stem Cells Dev 18:137-149.

WILLIS R A (1958) The Borderland of Embryology and Pathology. Butterworth and Co Ltd, London. 
Further Related Reading, published previously in the Int. J. Dev. Biol.

Embryo culture, stem cells and experimental modification of the embryonic genome. An interview with Professor Ralph Brinster Juan Arechaga

Int. J. Dev. Biol. (1998) 42: 861-878

Technique as the basis of experiment in developmental biology. An interview with Denis A.T. New Juan Arechaga

Int. J. Dev. Biol. (1997) 41: 139-152

Differentiation and transdifferentiation of normal and neoplastic cells

Ivan Damjanov

Int. J. Dev. Biol. (1996) 40: S63-S63

Teratocarcinoma: neoplastic lessons about normal embryogenesis

Ivan Damjanov

Int. J. Dev. Biol. (1993) 37: 39-46

On the boundary between development and neoplasia.

5 yr ISI Impact Factor $(2011)=2.959$

An interview with Professor G. Barry Pierce

Juan Arechaga

Int. J. Dev. Biol. (1993) 37: 5-16

Tradition and the present state of developmental biology in Yugoslavia Anton Svajger

Int. J. Dev. Biol. (1991) 35: 155-160

Developmental biology of the murine egg cylinder

Nikola Skreb, Davor Solter and Ivan Damjanov

Int. J. Dev. Biol. (1991) 35: 161-176

Why the mammalian embryo? An interview with Professor Nikola Skreb Drasko Serman

Int. J. Dev. Biol. (1991) 35: 149-154

In search of embryonic inductors. An interview with Sulo Toivonen Juan Arechaga

Int. J. Dev. Biol. (1989) 33: 9-14

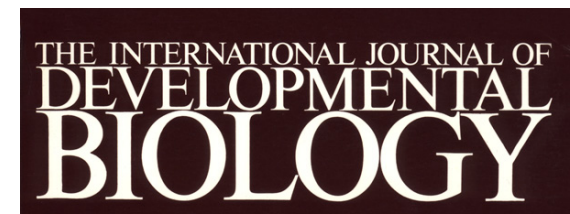

Volume 37 No. 1

March 1993

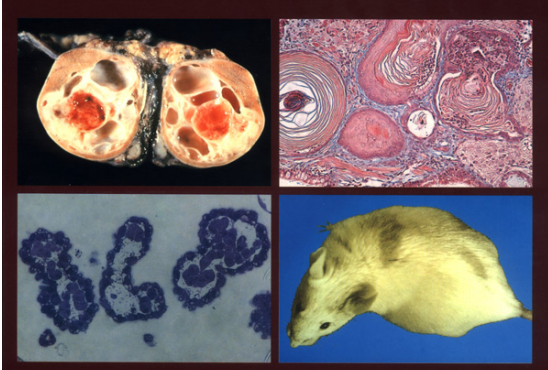

Developmental Aspects of Neoplasia

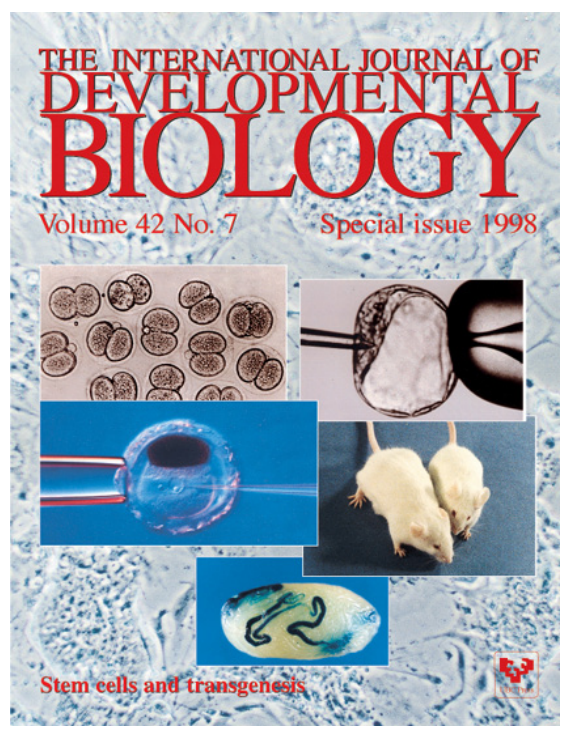

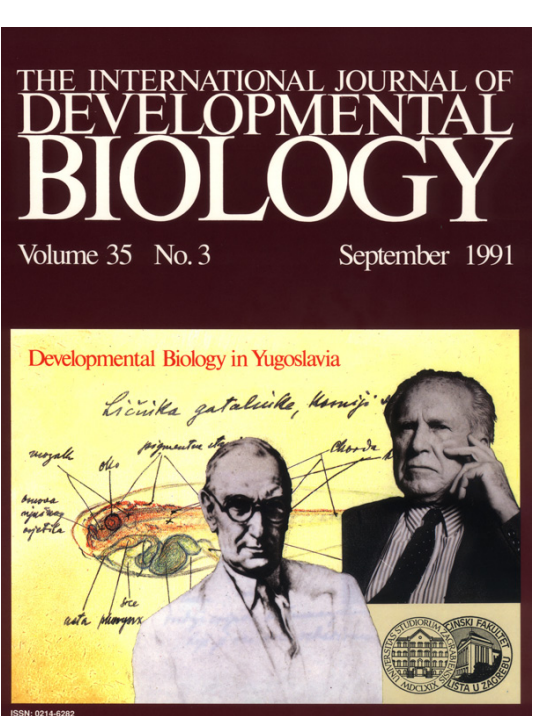

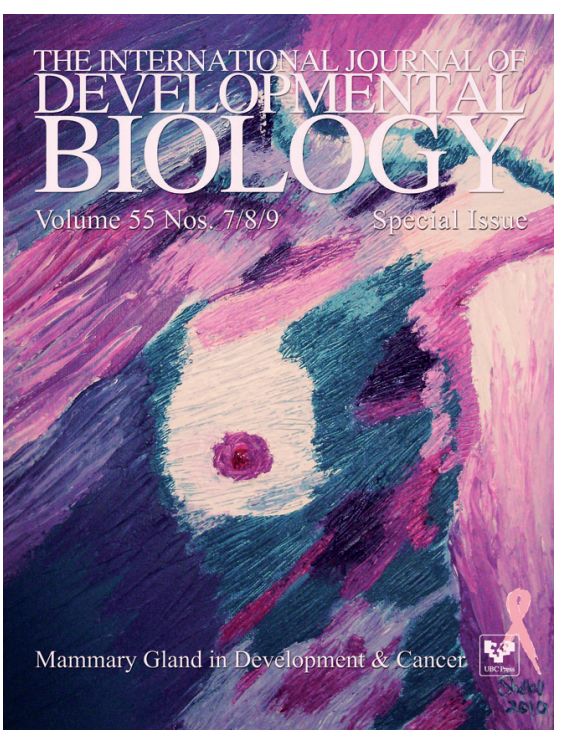

